\title{
GIS Based Analysis of Shoreline Change in Ibeno, Akwa Ibom State, Nigeria
}

\author{
F. U. Ekong \\ Department of Urban and Regional Planning, Faculty of Environmental Studies, University of Uyo, Uyo, Nigeria \\ Email: faith_ekong@yahoo.com
}

How to cite this paper: Ekong, F.U. (2017) GIS Based Analysis of Shoreline Change in Ibeno, Akwa Ibom State, Nigeria. Journal of Environmental Protection, 8, 637-649. https://doi.org/10.4236/jep.2017.85041

Received: April 7, 2017

Accepted: May 24, 2017

Published: May 27, 2017

Copyright $\odot 2017$ by author and Scientific Research Publishing Inc. This work is licensed under the Creative Commons Attribution International License (CC BY 4.0).

http://creativecommons.org/licenses/by/4.0/

\begin{abstract}
The study is an attempt to detect shoreline and land use change with a view to determining the trend and nature of the change in Ibeno, Akwa Ibom State, Nigeria. Landsat and Ikonos imageries and GIS techniques were utilized in capturing these changes over a period of 22 years (1986 to 2008) using 3 time periods. The result of the analysis indicated that there were more eroding than accretion portion in the shoreline of the study area. The study recommended monitoring of the shoreline change from time to time, establishment and enforcement of development setbacks, implementation of development control measures as well as the introduction of integrated coastal zone planning and management within the Niger Delta region to reduce hazards and protect the beautiful sand beaches.
\end{abstract}

\section{Keywords}

Coastal Area, Shoreline Change, GIS, Landuse Planning, Ibeno

\section{Introduction}

The coastal area is a highly dynamic environment with many physical processes such as tidal flooding, sea level rise, land subsidence and erosion/sedimentation. These physical processes play an important role in shoreline change and development of the coastal landscape. Shorelines are one of the most dynamic areas of the coastal environment. Shoreline is a line of contact between the land and the body of water [1]. In other words, it is the intersection of the land with the water surface. Defining a shore may be easy but capturing it may not be easy due to the dynamic nature of tides. Shorelines that are shown on charts represent the line of contact between the land and selected water elevation. However, in areas affected by tidal fluctuations, this line of contact is the mean high water mark line. In confined coastal water of diminished tidal influence, the mean through the 
mark may be used. Thus, changes in shoreline through the process of accretion and erosion can be analyzed using Geographic Information System (GIS) via measuring differences in the past and present shore line location.

The techniques of Remote Sensing (RS) and (GIS) have been increasingly used in combination to examine the spatial and temporal patterns of land use and land cover change especially as it relates to urban growth [2]. A combination of RS and GIS over time makes it possible for synoptic analysis of the earth system function, pattern and change at local, regional and global scales. More so, it becomes possible for land use and land cover change of area of interest to be mapped and monitored for specific needs [3]. Noted that the use of satellite remote sensing provides cost effective multi-spectral and multi-temporal advantages which may be processes of information valuable for understanding and monitoring land development patterns and process for building land use and land cover data for effective land use planning.

\subsection{Statement of Problem}

Coastal areas are faced with many human-induced environmental impacts. The human influence on coastal change contributes to the accelerated trend in sea level rise that threatens coastal habitats. Coastal zone globally is increasingly under pressure from human activities such as fishing, coral and sand mining, mangrove harvesting, sea weed farming, sewage disposal, urban expansion and tourism. Similarly, human activities which have profound negative impacts on coastal stability and shoreline change are dynamite fishing, over-harvesting of mangroves, coral and sand mining. Forests which help to stabilize coastline have also been threatened due to harvesting of mangroves for timber, fuel-wood and clearing for fishing resulting in habitat loss. As a result of the increased human population and oil exploitation especially oil-spills and gas flaring in the study area, anthropogenic impacts on the area have become severe overtime. There has been a large scale changes in land-use while in the major bar-beach along the Atlantic shoreline accretion seems to occur especially in Iwopom, Inuaeyet Ikot and Mkpanak communities. These human activities have distorted the natural state of the coastlines and also induced erosion and flooding in most parts of the area. Man quest to meet his insatiable needs drastically altered and threatened the stability of the shoreline.

The physical configurations of shoreline are dynamic and constantly changing due to waves' action which result in either erosion or accretion. The rate is determined by natural events as well as human actions that restrict the resources of sand for beaches and a coastal supply of sand is necessary for beaches to form and to be maintained along shoreline. Consequently, lack of beach replenishment creates vulnerability for shoreline which has always been subjected to varying level of erosion. Due to shoreline erosion, there has been a significant change in the Nigeria shoreline and every year the federal and state agencies spend a great deal of financial resources in protecting the beaches and structure from erosion. The problems confronting coastal areas are erosion, flooding and 
water pollution. These problems at the long run affect man-made infrastructure and degrade the coastal ecosystems. Addressing these problems is already a challenge which requires new approaches to manage the coastal area.

The main thrust of the present study, therefore, is that of making data available for planning purposes. The dynamic nature of shoreline makes its definition, mapping and monitoring a complicated task. This has created confusion and uncertainty for that using shoreline information for decision making and resource planning. However, to aid informed decision making, land-use planning and sustainable development of the coastal environment, there is need for data on both the current and historical shoreline trends including reliable measurement of erosion as well as accretion rate in non-stable areas. Hence, a detailed analysis of the shoreline change-rate would assist in a wide range of coastal management activities in hazard zoning and development setback planning.

\subsection{Aim and Objectives}

The aim of this study is to apply spatial GIS analytical techniques to detect rate of shoreline change in Ibeno and explore the possible implications for land-use planning in the area. The specific objectives are:

1) Extraction of the shore lines from the satellite imageries

2) Determining the trend and nature of land uses and land cover change.

3) Evaluating the rate of change in the shoreline over twenty-two years.

\section{Study Area}

The study area is located in the Niger Delta region of Nigeria. The area is a stretch of coastal area along the Bight of Bonny on the Atlantic Ocean. It has a shoreline approximately $56.7 \mathrm{~km}$ in length and spans from a point at Atabarikang village on latitude $4^{\circ} 31^{\prime} 23^{\prime} \mathrm{N}$ and longitude $7^{\circ} 49^{\prime} 16.0114^{\prime \prime} \mathrm{E}$ to Okposo village on latitude $4^{\circ} 34^{\prime} 09.7667^{\prime \prime} \mathrm{N}$ and longitude $8^{\circ} 17^{\prime} 52.6643^{\prime \prime E}$ (Figure 1).

The area has two distinct seasons namely the wet or rainy and the dry season. The climate characteristics correspond to Koppen's climate classification. It is characterized by very high rainfall (annual totals $>4000 \mathrm{~mm}$ ), high temperatures values of about $27^{\circ} \mathrm{C}$, and high values of relative humidity with mean value of $80.3 \%$. It has been suggested that shoreline erosion rates are expected to change in response to changes in climate [4]. Also, very high climatic factors will lead to increase in the rate of shoreline change. The present study is a move to show what has happened to the area with the current climate change.

The General vegetation class of the study area can be divided from the shoreline as mangrove/nypa palms/phoenix belt, the secondary forest, the oil palm and abandoned farmlands and fallowed areas. The geomorphology of the study area consists of level to gently undulating sandy plains. The terrain is heavily incised by numerous creeks, shallow streams, rivers, although, they are few and far between in the Northern part of the study area. Long rectilinear slopes (>400 m) with gentle inclinations of less than $50 \mathrm{~m}$, shallow depressions and water-logged valley bottoms constitute the major landforms. During the rainy season, many of 


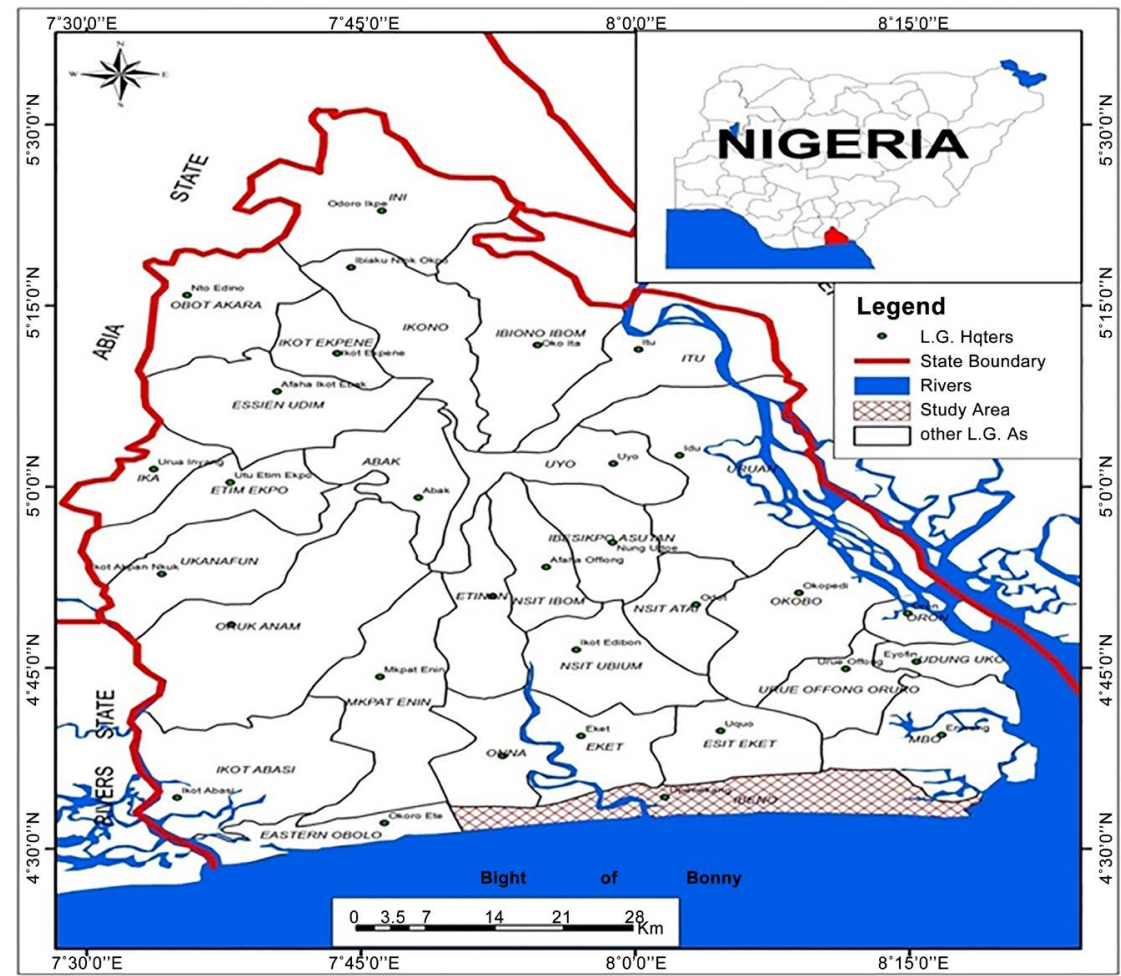

Figure 1. Map showing the study area.

the depressions may be inundated but consists of heaps of sand and sometimes thick deposits of clay when the water subsides. Generally, the relief of the study area ranges from less than 3 metres above sea level along the beach to about 45 metres inland. The gently-sloping beaches, wave breakers and a few small swamps systems are prone to flooding. The beaches were probably formed during development of coastal basins and trough spanning the entire gulf of Guinea in the cretaceous era [5].

Ibeno is drained by a number of rivers; on the Eastern and Southeastern part of the area is the Cross River which drained most part of the area. Also, draining the area is the Qua Iboe River which is the main drainage system of Akwa Ibom State. Ibeno is blessed with abundant surface water supply system. More so, increased rainfall amounts and intensities, storm surges and sediment supply from this drainage leads to greater rates of shoreline erosion. The porosity and permeability of the shoreline area affect the speed with which water can percolate into the ground. However, if the water moves underground, less runoff is generated thereby reducing the amount of surface erosion. Shoreline areas with more rain days tend to erode less than those with sand or silt.

In terms of the socio-economic activities in the area, there is a high level of dependence on natural resources for livelihood sustenance. Fishing is a male dominated enterprise while women dominate the gathering of periwinkles and crabs from the shallow swamps and dry season farming. The women also exploit the mangrove forest for fire wood and gathering of non-timber forest products such as mushroom, wild fruits and vegetables. They also process raw fish via 
drying or smoking and engage in farming of local food crops (cassava, yams, cocoyam, etc.).

Through the advent of oil exploration and the sitting of Exxon Mobil, Qua Iboe Terminal at Ibeno and migration of a large population the area has witnessed tremendous human activities. These human activities in turn result in the removal and disappearance of the native vegetation from the area thereby making the soil easily eroded. This study intends to investigate the change overtime in the area especially because of its importance the area holds for the economy of Akwa Ibom State and Nigeria as a major crude oil producing community.

\section{Literature Review and Conceptual Framework}

\subsection{Shoreline and Shoreline Changes}

Shoreline is defined as the position of the land-water interface at one instant in time and a highly dynamic feature on the landscape. According to a shoreline is a dynamic system with sediment moving continually, being deposited here and eroded there, as the shoreline attempts to establish equilibrium with respect to available sediment budget and prevailing near shore marine processes [6]. The shoreline is a valuable and important area which provides and activate habitat for fish and wildlife. In its natural state, the shoreline is perfectly engineer to protect against erosion and other coastal hazards as it provides structural integrity to the water edge thereby protecting it from soil erosion.

Recently, shoreline change is an issue of concern in the coastal planning and management as shoreline is constantly changing due to waves and tides. The changing shorelines have been influenced by people's actions throughout the years, this has taken place without an appreciation of the effect these actions could have on the coastal environment. Over $70 \%$ of the world's beaches are experiencing coastal erosion and this presents a serious hazard to many coastal regions [7]. More so, the coast being a dynamic and moving shoreline has been affected by many past decisions which were made without consideration of their effects on the wider environment. Thus, the weather, wind and tide are continually changing and the amount of physical change depends on many things and happens over time scales.

Shoreline changes occur in response to smaller-scale (short-term) events such as storms, regular wave action, tides and winds or in response to large-scale (long-term) events such as glaciations or orogenic (forces and effects) changes that may significantly alter sea levels (rise and fall) and tectonic activities that cause coastal land subsidence or emergence. Changes in the shoreline may result in new approaches that are necessary to manage future risks. In recent times, the use of GIS and RS for mapping and analyzing shoreline changes over a period of time has gained prominence as high resolution satellite data have become more readily available [8]. Shoreline change is best studied using GIS because of its ability to combine and compare satellite images of different time (years) of the same area [9]. Hence, the monitoring of shoreline changes may be derived from historical data that include topographical maps, aerial photographs and satellite 
images. These data can be easily combined and processed with the use of GIS giving much input for coastal planning and management.

The coast being a dynamic and moving shoreline has been affected by many past decisions which were made without consideration of their effects on the wider environment. Today, the weather, wind and tide are continually changing and the amount of physical change depends on many things and happens over time scale. However, shoreline changes may occur in response to smaller-scale (shore-term) events such as storms, regular wave action, tides and winds or in response to large-scale (long term) events such as glaciations or orogenic (for example the tectonic processes of sub-duction where the continent rides forcefully over an oceanic plate) changes that may significantly alter sea levels (rise and fall) and tectonic activities that cause coastal land subsidence or emergence [10].

\subsection{Land Use and Land Cover Change}

Land use is the utilization of land for different purposes such as residential, commercial, agriculture, industrial, etc. Land use describes how land cover is modified as a result of man's activities on land. Land cover on the other hand refers to the physical and biological cover of the surface of land which includes water, vegetation, bare soil and artificial structures.

Land cover includes natural vegetation, artificial cover, rock/soil and other noticeable features on land. Land cover is a conglomeration of the biotic and abiotic components of the earth. Land use and land cover change are dynamic and they involve the direct and indirect modification of the natural habits. Although, changes in land use and land cover may involve the nature or intensity of change they also include the spatial and time aspects. Over the years, land use and land cover change has been a major concern for major stakeholders in the environment that is why the scientific Research Community called for the substantive study of land use changes during the 1992 United Nations Conference on Environment and Development. Changes in land use and land cover are as a result of the direct and indirect consequences of human actions to obtain food and other essential resources [11]. However, these changes encompass the greatest environmental concerns of human populations including climate change, biodiversity loss and the pollution of water, soils and air.

One of the most dynamic processes in the coastal area is the shoreline change and in order to mitigate coastal hazards or plan for future use of the coastal area, the mapping of shoreline changes becomes inevitable. Different methods exist to aid in the mapping of shoreline changes as well as shoreline extraction. In recent years, satellite remote sensing data has been used in shoreline extraction and mapping. However, studies on shoreline change detection have attracted the attention of researchers worldwide. Many researchers carried out analysis of shoreline change using the combination of MSS Landsat and land use maps. In those studies, the shoreline change were evaluated using remote sensing to calculate the index of changes which was done by the superimposition of land 
use land cover images [12] [13]. This was done to analyse the pattern of change in the area over the period.

Furthermore, on-screen digitizing had been used to delineate the shorelines while multi-temporal and multi-spectral-land data were used to determine change around Tuz lake on Seyhan Delta [14]. After the digitizing process, the rector format was transferred to raster format. Through spatial analysis, the shape of the river mouth and sandy area in hectare were successfully detected and calculated. Also, the changes of the Seyhan river mouth and the related shoreline from 1972 to 2000 were determined. A group of researchers used Ikonos Stereo imagery in shoreline extraction. They [15] presented the results of an experiment in which they attempted to improve Ikonos Rational Functions (RF) for a better ground accuracy and to empty the improved RF for a 3-D shoreline extraction using 1-metre panchromatic stereo images in Lake Erie coastal area. In this method, a 2D shoreline is extracted by manual digitizing on one Ikonos image; the corresponding shoreline points on the other image of the stereo-pair are automatically extracted by image matching. The $3 \mathrm{D}$ shoreline is computed using photogrammetric triangulation can be computed using pixel-based segmentation on Ikonos image using DN threshold. The partition of the land and sea boundary was done using Pseudo-colour which exhibits a strong contrast between land and water features. More so, they assessed multi data sources for monitoring shoreline in Kuala Terenggamu, Malaysia using Ikonos and aerial photographs. Results of time series data were combined to each other showing spatial change of shoreline.

In most of the aforementioned methods, the shoreline extraction using Ikonosorthormagery is based in land cover classification to discriminate the pixel corresponding to water bodies from those corresponding to land. Hence, the resulting thematic image is converted to image coverage usually a polygon shape file containing the polygons corresponding to each class. The shoreline is finally extracted from the polygon that corresponds to water by employing automatic or semi-automatic GIS procedures. Thus, the accuracy of the image orthorectification as well as the accuracy of the image classification is the most important factor affecting the accuracy of the extracted shoreline. However, a wide range of applications could be made possible with the accurate estimation of the historical shoreline change rates but the challenge is that the calculations involved in the trend analysis of the shorelines are very complex due to its Spatio-temporal variability.

On the other hand, future shoreline position prediction models are essential to effectively determine the changes to coastal line as well as enable us to save the structural and financial losses in the coastal region. Also, the physical planning authorities and other users of the coastal zone, shoreline forms a major tool for the day to day planning activities. Although, shoreline prediction model would provide a better estimation of the coastal erosion, other methods exist and studies have been embarked upon by researchers to determine the most appropriate method based on either a comparative approach or the prediction of 
known positions. The End Point Rate (EPR) method is an empirical equation which shows that the future position of the shoreline can be derived by a linear relationship between past shoreline. The EPR method uses only two data points to delineate a change rate,-the earliest and most recent shoreline positions. The main disadvantage of this method is that if one or both end points are erroneous, the calculated erosion rate will be inaccurate. The change rate $(\mathrm{m})$ and intercept (c) involved in this model are derived by a line $(y=m+c)$ extracted from this points on the earliest and latest available shorelines ( $y$ and $x$ represent the shoreline position and time respectively). The model results showed that approximately $17 \%$ of the shoreline has become more eroded in the study area, while more than $80 \%$ of the shoreline was well protected by structural protection.

The Jackknife (JKF) is the method which is used as an iterative linear regression. The slope of the linear regression lines are averaged to yield the jackknife rate. The main disadvantage of the jackknife method is a lack of increased statistics value given the typically small number of shoreline data points used to derive a shoreline rate of change. Another popular method is the transect based method which is a traditional and mapping approach used among coastal engineers and planners to analyze shoreline changes. This approach involves the subdivision of available shorelines into smaller segments by creating transects at a master shoreline. The master shoreline is a shoreline with a good quality and transects are at the right angles to this master shorelines. Once transects are created, the rates of shoreline change are calculated along these transects to observe the historical shoreline movements. Thus, the future shoreline position can be derived using these change rates.

The concept applicable to this study is the dynamic segmentation concept. The basic idea in this concept is to maintain the continuity of the shoreline. This model acknowledges the subdivision of continuous shoreline into smaller sections. A more appropriate structure in the dynamic segmentation is where a line feature is divided into segments by recording the location of a change in attribute or an event using a distance along the line from a specified origin or topological node without breaking the actual line into pieces. In the implementation of dynamic segmentation, the term route is given to any linear feature such as highway, river, shoreline etc, regardless of the number of arcs that makes up its representation within the database.

\section{Materials and Methods}

The study acquired data through the use of maps, aerial photographs and Global Positioning System (GPS). The study also utilized data from satellite imagery. The satellite imagery used for the study was Landsat TM 1986 and Landsat ETM 2008 of 30 m ground resolution and 2008 Ikono imagery of $1 \mathrm{~m}$ ground resolution. This study will cover 1986-2008 periods only. The period was chosen based on the fact that the raining seasons of 2007 and 2008 witnessed heavy rainfall and massive erosion which washed away many small fishing ports located along 
the Atlantic coastline in the region. The other issue is that of limited availability of cloud-free imageries covering the study area. These imageries were processed and analysed to produce the land use cover change map of the area and to also delineate the shorelines of different periods with the view to determine their rate of change. The GPS was used to acquire ancillary and also capture the sites visited.

Two forms of spatial analysis were used to achieve the first objective i.e. the area calculation of the land use/cover from each year and post-classification change detection. The area calculation involved comparison of the land-use change statistics derived from the classified images while the post classification change is an area specific change detection procedure (point-by-point). The point-by-point method was used for the change detection. After the images were classified and change detection carried out, the actual cartographic production of the land use/cover maps and generation of statistics for inventory were completed using ArcGis 9.1.

The determination of a shoreline reference feature was the next step; a shoreline reference feature was used as a basis for measurements/digitization. The High Water Line (HWL) was used in this study because it was easily distinguishable on all the imageries as a wet/dry line especially on the Ikonos imagery. The on-screen digitization method was used to perform the extraction while the end point rate method was used to calculate the distance of the shoreline movement. The rate of shoreline change was computed using the Digital Shoreline Analysis System (DSAS).

\section{Results and Discussion}

The study area was classified into five land use/cover change classes: compound farmland, bush fallow, imperfectly drained farmland, forest and open water. The result of the land use change detection carried out is summarized in Table 1.

The table reveals that open water and compound farmland have expanded in some area between 1986 and 2008, while mangrove swamp forest, bush fallowing and fresh water swamp forest experienced reduction. Despite the marginal increase detected in the area covered by open water it has been the most stable expanding by $4 \mathrm{~km}^{2}$ in 17 years with $0.24 \mathrm{~km}^{2}$ of change per year. The effect of erosion on shoreline due to increase in open water is shown on Figure 2.

Bush fallowing decreased by $0.76 \mathrm{~km}^{2}$ annually while compound farmland recorded the highest expansion accounting for about $4 \%$ of the total change in the study area. Settlement/built-up areas and farmland were classified as compound farmland as there is no difference in the spectral value of the two features during classification of the landsat imageries. The land-use change cover analysis of the study area showed a marginal change in the open water which is increasing at the rate of $13.70 \mathrm{~km}^{2}$ per year and compound farmland which is increasing at the rate of $351.20 \mathrm{~km}^{2}$ per year. The actual locations of the changes were also examined in order to confirm the pattern and trend that is inherent in the process of land-use conversion and modification. 
Table 2 reveals that $80.5 \mathrm{~km}^{2}$ and $34.04 \mathrm{~km}^{2}$ has been converted to bush fallow and compound farmland respectively. $167.14 \mathrm{~km}^{2}$ of compound farmland has been converted to bush fallowing. This implies that bush fallowing and compound farmland are the dominant land-use systems in the area.

Shoreline extraction was carried out via on-screen digitizing method. The shorelines from the land-sat imageries of 1986, 2006 and 2008 Ikonos imagery were mapped using the on-screen digitizing method in ArcGis environment. Figure 3 depicts the result of the extracted shorelines by on-screen digitization while Table 3 show values.

Table 1. Land use inventory and change Detection state.

\begin{tabular}{ccccccc}
\hline S/N & Land use Type & $1986\left(\mathrm{~km}^{2}\right)$ & $2008\left(\mathrm{~km}^{2}\right)$ & $\begin{array}{c}\text { Change } \\
\left(\mathrm{km}^{2}\right)\end{array}$ & $\begin{array}{c}\text { Change/yr } \\
\left(\mathrm{km}^{2}\right)\end{array}$ & $\begin{array}{c}\text { Total }(\%) \\
\text { change }\end{array}$ \\
\hline 1 & $\begin{array}{c}\text { Open water } \\
\text { Mangrove } \\
\text { forest }\end{array}$ & 66549.2 & 66823.27 & +13.70 & +13.70 & 1.85 \\
2 & 7011.99 & 3654.55 & -3357.44 & -167.87 & 22.64 \\
3 & $\begin{array}{c}\text { Fresh water } \\
\text { forest }\end{array}$ & 24779.5 & 21609.80 & -3169.70 & -158.485 & 21.37 \\
& $\begin{array}{l}\text { Bush } \\
\text { Fallowing }\end{array}$ & 18132.1 & 17125.20 & -10006.90 & -50.345 & 6.79 \\
5 & $\begin{array}{c}\text { Compound } \\
\text { Farmland }\end{array}$ & 19442.05 & 26466.16 & +7024.11 & +351.20 & 47.35 \\
& Total & $135,914.84$ & $135,914.84$ & 14832.22 & 741.60 & 100 \\
\hline
\end{tabular}

Source: extracted from Landsat imageries.

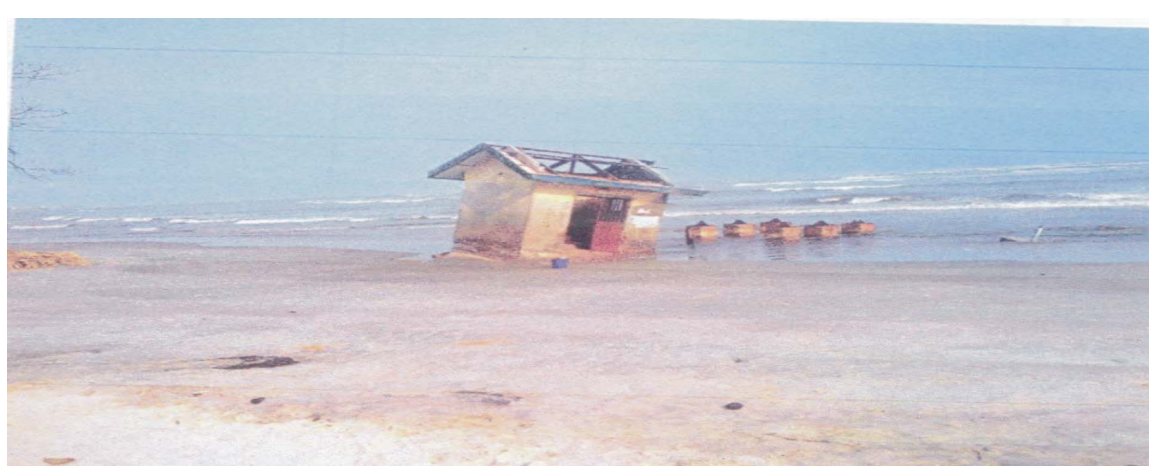

Figure 2. The remains of a three star hotel on the sand beach.

Table 2. Land use change Matrix.

\begin{tabular}{cccccc}
\hline Land use type & Open water & $\begin{array}{c}\text { Mangrove } \\
\text { Swamp water }\end{array}$ & Forest & $\begin{array}{c}\text { Bush } \\
\text { Fallowing }\end{array}$ & $\begin{array}{c}\text { Compound } \\
\text { Farmland }\end{array}$ \\
\hline $\begin{array}{c}\text { Open water } \\
\text { Mangrove }\end{array}$ & No change & 0.18 & 1.40 & 0 & 0.79 \\
Forest & 1.00 & No change & & 3.49 & 5.01 \\
$\begin{array}{c}\text { Bush Fallowing } \\
\text { Compound } \\
\text { Farmland }\end{array}$ & 0.77 & 14.66 & No & 80.5 & 34.04 \\
\hline
\end{tabular}

Source: extracted from imageries. 


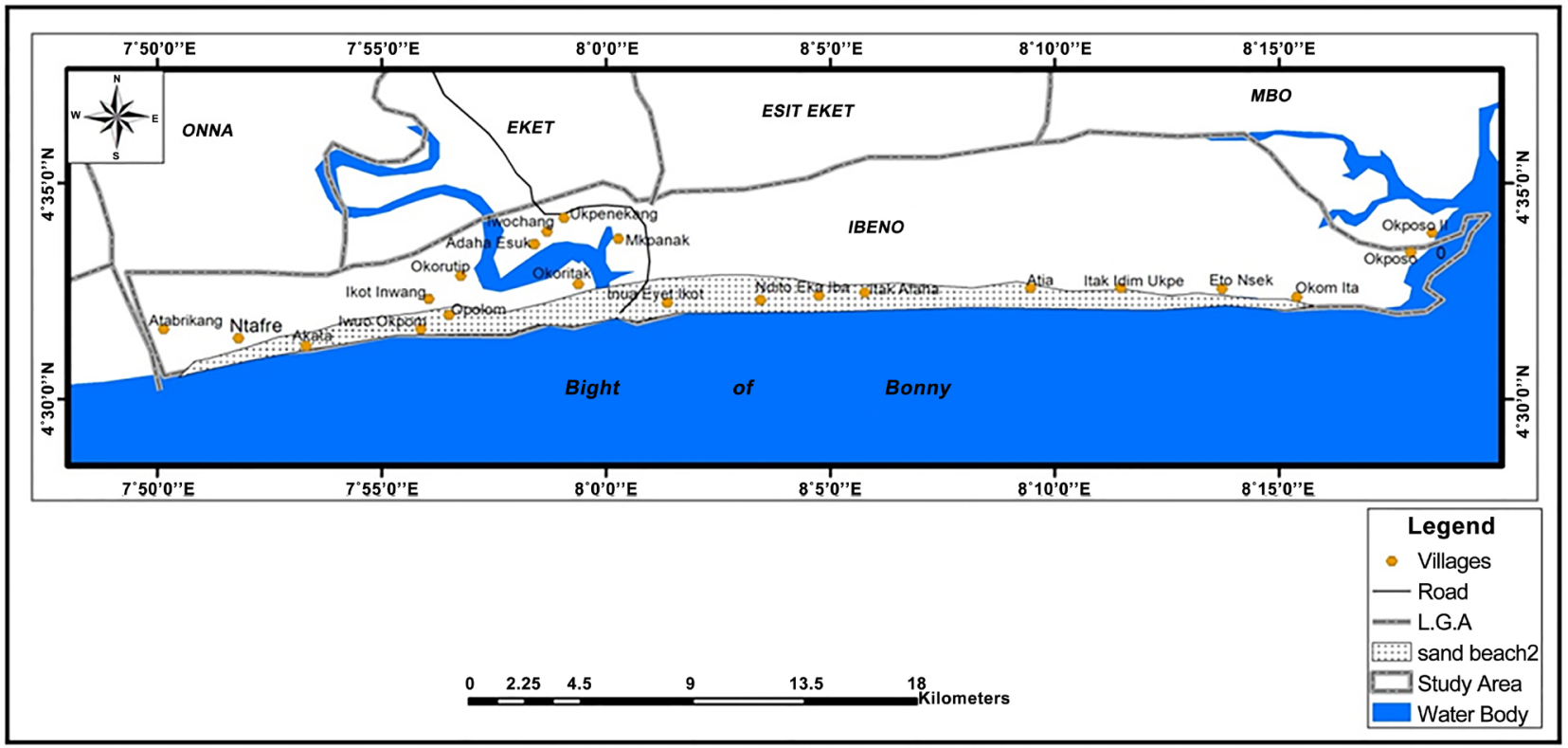

Figure 3. Extracted shoreline showing accretion.

Table 3. Shoreline Erosion, Accretion and Net change in meter.

\begin{tabular}{cccc}
\hline Period & Accretion $(\mathrm{m})$ & Erosion $(\mathrm{m})$ & Net change $(\mathrm{m})$ \\
\hline $1986-2006$ & 1472.42 & -32905.2 & -31432.78 \\
$2006-2008$ & 4074.28 & -3714.1 & 360.18 \\
$1986-2008$ & 2618.38 & -33691.2 & -31072.82 \\
\hline
\end{tabular}

Source: extracted from Landsat 1986 and Ikonos 2006 and 2008.

The total length of the extracted shoreline from 1986 land-sat image was $46.162 \mathrm{~km}$ that of 2006 was $45.811 \mathrm{~km}$ while that of 2008 Ikonos imagery was $45.942 \mathrm{~km}$. The different lengths in the extracted shorelines indicate that there has been a change in the shoreline under study.

On the whole, it was observed using the end point rate that during 1986 to 2006, the shoreline net erosion change was in the magnitude of $-31432.78 \mathrm{~m}$ while from 2006 to 2008 the shoreline net accretion change was $360.18 \mathrm{~m}$. The rate of change of the shoreline was assessed using 449 transects of equal distance of 100 metres built across the entire shoreline under study. From the result of the 449 transect lines measured, 45 showed accretion (range: $0.002 \mathrm{~m} / \mathrm{yr}$ to 6.44 $\mathrm{m} / \mathrm{yr}$ ). The average erosion rate of change for the entire study was $-3.9 \mathrm{~m} / \mathrm{yr}$ while the average accretion rate change for the entire study was $2 \mathrm{~m} / \mathrm{yr}$. It was noted that most of the places affected by minimal erosion was as a result of engineering activities going on in the area while some were caused by human activities at the river estuary along the shoreline. The accretion near Exxon Mobil was as a result of sand filling done in the past for settlement development.

\section{Conclusion and Recommendation}

The findings of this study have revealed that there are more eroding than ac- 
creting portions for all the periods across the entire shoreline. This is as a result of human activities e.g. laying of pipelines carried out at the river estuary along the shoreline. This implies that infrastructures will be threatened when sited near eroding portions along the shoreline. Also, the accreting regions can pose a threat when jetties are sited close to them. Nevertheless, the following physical planning measures could be put in place to minimize the impact of human activities.

\subsection{Monitoring of the Shoreline Change}

There is the need to monitor the pace/rate of change along the shoreline in order to detect eroding areas. To monitor the shoreline change effectively, satellite imageries should be acquired from time-to-time along the Nigerian coast; this will give a clear picture of the change over time. However, Ikonos satellite imagery or imageries with high resolution (e.g. $1 \mathrm{~m}$ and below) always have the potential for shoreline mapping and erosion monitoring; this is because the High Water Line (HWL) is always easy to extract from these imageries. More so, the state government should build embankments to salvage erosion in the eroding portions of the area.

\subsection{Establishment and Enforcement of Standards}

There should be standards e.g. building line/setbacks to ensure that infrastructures, structures whether temporary or permanent are not sited too close to the shoreline so that they are not affected. Hence, development control measures should be strictly implemented to ensure that buildings and other structures are built in the appropriate zones and development plans should be approved by the planning authorities. Due to the dynamic nature of coastal shorelines, development in the area should be carried out within the context of Integrated Coastal Planning and Management (ICPM) policy involving land-use zoning for community infrastructures, structures, agriculture, industry, etc. Hence, acceptable and permitted uses must be consistent with the standards. Uses should be limited to those types of development activities that are not detrimental and capable of impacting adversely or negatively on the coastal environment.

\subsection{Planting and Replanting of Mangrove Seedlings}

The re-vegetation of areas destroyed by nipa palm invasion is urgently needed by using women groups who depend on the exploitation of natural resources like fish, periwinkle, prawn, oyster, etc. and Community Based Organisations (CBOs) to start pilot mangrove seedling planting programme. The fast growing red mangrove species (Rhizophora racemosa) is recommended for this pilot project.

\section{References}

[1] Gens, R. (2010) Remote Sensing of Coastlines. Detection, Extraction and Monitoring. International Journal of Remote Sensing, 31, 1819-1836.

https://doi.org/10.1080/01431160902926673 
[2] Chen, S., Zeng, S. and Xie, C. (2000) Remote Sensing and GIS for Urban Growth Analysis in China. Photogrammetric, Engineering and Remote Sensing, 66, 593598.

[3] Weng, O. (2002) Land Use Changes Analysis in the Zhujiang Delta of China Using Satellite Remote Sensing GIS and Stochastic Modeling, Journal of Environmental Management, 64, 273-284. https://doi.org/10.1006/jema.2001.0509

[4] Atser, J., Etim, N., Beulah O. and Ekong F. (2010) An Overview of the Changing Pattern of Rainfall and Its Implication for Environmental and Agricultural Development, Akwa Ibom State, Nigeria: A Case Study, Journal of Agriculture and Social Sciences, 3, 67-72.

[5] AKIPOFTZ (2015) Freetrade Zone in Ibaka, Mbo L.G.A, Government of Akwa Ibom State.

[6] Parker, B.B. (2003) The Difficulties in Measuring a Consistently Defined Shoreline. Journal of Coastal Research, 38, 44-56.

[7] Appeaning, A.K., Waikden, M. and Mills, J.P. (2008) Detection, Measurement and Prediction of Shoreline Recession in Accra, Journal of Photogrammetry and Remote Sensing, 63, 543-558. https://doi.org/10.1016/j.isprsjprs.2008.04.001

[8] Adegoke, J.O., Fagbeja, M., James, G., Agbaje, G. and Ologunorisa, T.E. (2010) An Assessment of Recent Changes in the Niger Delta Coastline Using Satellite Imagery. Journal of Sustainable Development, 3, 277-296.

[9] Eludoyin, O.S., Oduore, T. and Obafemi, A.A. (2012) Spatio-Temporal Analysis of Shoreline Change in Bonny Island, Nigeria. Ethiopian Journal of Environment Studies and Management, 5, 123-130.

[10] Braatz, S., Fortuna, S., Broadhead, J. and Leslie, R. (2006) Coastal Protection in the Aftermath of the India Ocean Tsunami: What Role for Forests and Trees? Proceedings of the Regional Technical Workshop, Khao Lak, Thailand, 28-31 August 2006, $5-33$.

[11] Ellis, E. (2013) Land-Use and Land-Cover Change. http://www.ecotope.org/people/ellis/papers/ellis_eoe_lulcc_2007.pdf

[12] Dimyati, A. (1995) Analysis of Land Use/Land Cover Change Using the Combination of Mss Landsat and Land Use Map: A Case Study of Yogyakarta, Indonesia. International Journal of Remote Sensing, 17, 931-944. https://doi.org/10.1080/01431169608949056

[13] Yu, S., Yi, M., Xu, D., You, X., Long Z. and Wu, Z. (2013) A New Algorithm for Shoreline Extraction from Satellite Imagery with Non-Separable Wavelet and Level Set Method, International Journal of Machine Learning and Computing, 3, 158-163. https://doi.org/10.7763/IJMLC.2013.V3.293

[14] Liu, H and Jezek, H.C. (2004) Automated Extraction of Coastline from Satellite Imagery by Integrating Canny Edge Detection and Locally Adaptive Thresholding Methods. International Journal of Remote Sensing, 25, 937-958. https://doi.org/10.1080/0143116031000139890

[15] Li, R., Di, K. and Ma, R. (2003) 3-D Shoreline Extraction from Ikonos Satellite Imagery. Marine Geodesy, 26, 107-115. https://doi.org/10.1080/01490410306699 
Submit or recommend next manuscript to SCIRP and we will provide best service for you:

Accepting pre-submission inquiries through Email, Facebook, LinkedIn, Twitter, etc. A wide selection of journals (inclusive of 9 subjects, more than 200 journals)

Providing 24-hour high-quality service

User-friendly online submission system

Fair and swift peer-review system

Efficient typesetting and proofreading procedure

Display of the result of downloads and visits, as well as the number of cited articles Maximum dissemination of your research work

Submit your manuscript at: http://papersubmission.scirp.org/

Or contact jep@scirp.org 